\title{
A Letter from the Editors
}

\author{
Hakon Caspersen and Inna Yaneva-Toraman
}

\author{
Volume 4, Issue 1 \\ Imagining the Future
}

Time often reveals itself through the sudden realization of years passed, time lost or days enjoyed - a remembrance of the now-old then-alive moments. In such instances, time materialises in our minds as a merciless current, an uncontrollable force greater than anything we can endure. Yet, despite our sense of time as flowing, the future appears to us as a stationary mystery somewhere ahead. It holds multiple 'worlds' and possibilities that we can reach. Through our ability to imagine these futures we gain a sense of purpose and directionality; we push against the current of time towards envisioned lives-to-be. This issue of The Unfamiliar invites us to 'see' the future not as something distant or unknown, but as something concrete - visible in our actions, hopes, and desires. It shows that both imagination and the future cannot be divorced from peoples' daily lives and experiences, and that 'imagining the future' is, in fact, deeply embedded within the practices of both our past and present. The future, thus, becomes real, meaningful, significant, and tangible through lived experience.

The contributors to this issue all seek to elucidate this connection between lived experience, imagination, and the future in their own distinct way. For instance, Fahye describes how over the last 40 years an international community of Hare Krishna devotees in Mayapur, India, have been working towards a prophesied 'Ideal Vedic City'. Through ritual practices such as katha (a form of storytelling), devotees draw upon the central virtues, ideals, and moral guidelines found in stories of an 'enchanted past' in order to transform themselves and the present towards an aspired future. Exploring similar themes, on a larger scale, Kuldova directs our attention to the utopian vision of India's future 'superpowerdom'. She shows how Hindu nationalism and the philanthropy of the Indian business elite have taken inspiration from India's 'golden' pre-colonial past as they both promote the country's inevitable success. Her work illustrates how the imagined future is materialized in the aesthetics of ornamentalist fashion and the design of futuristic smart cities. Paradoxically, Kuldova asserts, the propagators of this 'myth' all knew that "the reality looks radically different" while "still act[ing] as if they didn't know, investing their own capital in... projects destined to never look like their promotional images". What this points to, are the pervasive imaginative power and material consequences of "shared illusions" and "mythical narratives" in shaping and directing future actions. This imagined future of India is then brought before our eyes with Ian Cook's photographic essay of Mangalore, a small city on the country's South-West coast. Through various photographs of billboards depicting massive residential complexes, his work illustrates how promotional images play a significant role in the production of the city's imagined future. With this inspiring work, Cook pushes us to see the billboards not as mere images - representations of an imagined future -, but as pieces of the cityscape that bring the 'big' future into the 'small' present.

The piece by Bachelet and Houdou effectively demonstrates the significance of hope in migrants' lives when thinking about the future. It takes us to Douar Hajja, a neighbourhood in Rabat, Morocco, where migrants in transit wait, heal, plan, and hope. Through the powerful image and poem we are reminded that hope for the future may as well be deeply intertwined with despair for the present. On the other hand, Maggio's creative essay takes us to the realm of dreams where layers of the past, present, and future come together in an ever-changing representation of lived experience. Starting with the analysis of a dream, the author then moves to the problems of representation: Where are the people in ethnographic writing? What is the difference between text and photographs? How can we truly represent the people from our fieldwork? Addressing such questions, this essay provides a different look into the future: the future of ethnographic writing. Last in this section, the poem by Emily Lynn Cook explores the relationship between desire and perception and the ways in which they shape dreams of the future. Her work offers interesting insight into the effects of imagined futures on human experience and anthropological understandings of the 'other'.

In the second part of this issue Kyriakides suggests a different approach to the subject by examining the relationship between stillness and imagination. He argues that stillness is not simply a 
lack of action, but rather a practice of imaginative labour and an agency for political transformation. Through various examples of stillness, both in art and political activism, Kyriakides shows that even things that seem radically different, like a fighter and a thinker, can work towards a "common political project of producing and maintaining imagination". In this essay, the future takes form through the very potentiality of imaginative labour, it appears in the stillness of resistance, writing, and thinking. Finally, bringing this volume to a close, Michael Shea offers an ethnographic glimpse into the imagined future of Japan in the aftermath of the Tohoku earthquake and tsunami on the $11^{\text {th }}$ of March, 2011. By examining the ways in which the future is imagined and made present within a Japanese science and technology museum, and more specifically, through a temporary exhibition staged as a direct response to these catastrophic events, this essay demonstrates how particular events of the past can shape people's vision of the future. This exhibition, we are informed, differs in content and meaning from conventional techno-utopian visions of the future and instead encourages visitors' to reflect on their own mortality, and to accept the uncertainty of the future, in direct response to the recent events.

We are grateful to all contributors and hope you will find this issue of The Unfamiliar an enjoyable read. But before we turn our gaze towards the future, we would like to use this opportunity to acknowledge the hard work and dedication of the journal's previous executive editors Grit Wesser and Jona Fras. We delight in the opportunity to carry on the torch as executive editors and wish them all the best in future endeavours. 